\title{
The Crystal and Molecular Structure of $\operatorname{Bis}\left(N^{1}\right.$-isopropyl-2- methyl-1,2-propanediamine) [(S)-lactato ]zinc(II) (S)-Lactate Monohydrate
}

\author{
MARKKU AHLGRÉN, URHO TURPEINEN and REIJO HÄMÄLÄINEN
}

Department of Inorganic Chemistry, University of Helsinki, SF-00100 Helsinki 10, Finland

The structure of bis $\left(N^{1}\right.$-isopropyl-2-methyl-1,2-propanediamine) $[(S)$-lactato]zinc(II) (S)-lactate monohydrate has been determined from three-dimensional $\mathrm{X}$-ray data and refined by full-matrix least-squares to a final $R$ value of 0.049 for 1795 reflections. The crystals are monoclinic, space group $P 2_{1}$, with $a=8.818(3), b=18.887(5), c=8.500(2) \AA$ and $\beta=$ $102.13(2)^{\circ}$. The zinc coordination is distorted trigonal bipyramidal with a carboxyl oxygen atom $[2.009(5) \AA]$ and two nitrogen atoms $[2.004(8)$ and $2.095(6) \AA]$ forming the equatorial coordination plane and with the nitrogen atoms bonded to isopropyl groups in the axial positions [2.234(8) and $2.264(7) \AA]$. Complex cations, (S)-lactate ions and water molecules form a hydrogen bonding network.

Complex formation in aqueous solution between copper(II) and 1,2-propanediamine and substituted 1,2-propanediamine has recently been investigated in this laboratory. ${ }^{1}$ Crystallographic analyses of some mono- and bis $\left(N^{1}\right.$-isopropyl-2-methyl-1,2propanediamine)copper(II) carboxylates have also been carried out. ${ }^{2-5}$ In all bis $\left(N^{1}\right.$-isopropyl-2methyl-1,2-propanediamine)copper(II) carboxylates so far examined, the coordination sphere of $\mathrm{Cu}$ (II) is square pyramidal with the apical position occupied by the oxygen atom of a carboxyl group. The apical $\mathrm{Cu}-\mathrm{O}$ distances of $2.23 \AA$ in tartrate ${ }^{5}$ and malate ${ }^{6}$ complexes and $2.16 \AA$ in succinate, ${ }^{6}$ fumarate ${ }^{6}$ and lactate ${ }^{4}$ complexes are only $0.1-0.2$ $\AA$ longer than the basal $\mathrm{Cu}-\mathrm{N}$ distances and the $\mathrm{Cu}$ atoms are appreciably lifted $(0.19-0.33 \AA)$ from the basal planes.

To investigate further $N^{1}$-isopropyl-2-methyl-1,2propanediamine transitio-metal carboxylates, we prepared the $\operatorname{bis}\left(N^{1}\right.$-isopropyl-2-methyl-1,2-pro-
panediamine)zinc(II) (S)-lactate. Preliminary X-ray work indicated that the zinc(II) compound is isomorphous with the copper(II) compound. Likewise the IR-spectra of the two compounds are very similar. A slight increase in the separation of the antisymmetric and symmetric stretching frequencies of the unidentate carboxyl group in the zinc(II) compound may be due to stronger bonding of the lactate group. ${ }^{7}$ To investigate this supposition we have made an X-ray structural analysis of the zinc(II) compound and report the results in this paper.

\section{EXPERIMENTAL}

Colourless crystals were obtained by slow evaporation of a water-ethanol solution containing zinc(II) oxide, L-lactic acid and $\mathrm{N}^{1}$-isopropyl-2methyl-1,2-propanediamine in molar ratio $1: 2: 3$. A single crystal of dimensions $0.3 \times 0.3 \times 0.5 \mathrm{~mm}$ was selected for the $\mathrm{X}$-ray investigation.

Lattice parameters were obtained from leastsquares refinement of eighteen well-centered reflections measured on a Syntex $\mathrm{P} 2_{1}$ diffractometer using graphite monochromatized $\mathrm{Mo} K \alpha$ radiation $(\lambda=0.71069 \AA)$. Crystal data: $a=8.818(3), b=$ 18.887(5), $c=8.500(2) \AA, \beta=102.13(2)^{\circ}, Z=2, D_{\mathrm{m}}=$ $1.25(1), D_{\mathrm{c}}=1.25 \mathrm{~g} \mathrm{~cm}^{-3}$, space group $\mathrm{P} 2_{1}, \mu(\mathrm{MoK} \alpha)$ $=9.6 \mathrm{~cm}^{-1}$.

Intensity data were collected $\left(5<2 \theta<50^{\circ}\right)$ at room temperature using the $\omega$-scan technique and a scan rate varying from 2.0 to $30.0^{\circ} \mathrm{min}^{-1}$ depending upon the peak intensity. The intensity of one check reflection, recorded after every 99 measurements, remained essentially constant throughout the data collection. Out of 2521 independent reflections measured, 1795 had $I>3 \sigma(I)$, and were used in the structure determination. The data were corrected 
for Lorentz and polarization factors and for absorption from $\phi$-scan data.

\section{STRUCTURE DETERMINATION AND REFINEMENT}

The initial positions of the nonhydrogen atoms were taken from the corresponding copper(II) compound, ${ }^{4}$ with $\mathrm{Cu}$ replaced by $\mathrm{Zn}$, and five cycles of least-squares refinement were run on these positions using isotropic thermal parameters. The conventional agreement factor $R=\Sigma|| F_{\mathrm{o}}|-| F_{\mathrm{c}}|| /$ $\Sigma\left|F_{\mathrm{o}}\right|$ was 0.092 .

Anomalous dispersion corrections were included for $\mathrm{Zn}^{8}$ and refinement with anisotropic temperature factors for nonhydrogen atoms gave $R=0.060$. The function minimized was $\Sigma w\left(\left|F_{\mathrm{o}}\right|-\left|F_{\mathrm{c}}\right|\right)^{2}$ with $w=1 / \sigma^{2}\left(F_{\mathrm{o}}\right)$. At this stage the hydrogen atoms were included in the calculated positions $(\mathrm{X}-\mathrm{H}=1.0 \AA$ and $U_{\text {iso }}=0.06 \AA^{2}$ ) and not refined since all hydrogen atoms could not be found unambiguously from a difference Fourier map. A full-matrix refinement based on 1795 reflections and 289 variables yielded $R=0.049$, the average shift/error ratio in the last cycle being 0.09 . Scattering factors for nonhydrogen atoms were from Cromer \& $\mathrm{Mann}^{9}$ and for $\mathrm{H}$ atoms from Stewart, Davidson and Simpson. ${ }^{10}$ The largest peak on a final difference map was close to $\mathrm{Zn}$ and had a density of $0.5 \mathrm{e} \AA^{-3}$. The computations were performed on a Univac 1108 computer with the X-RAY 76 program system. ${ }^{11}$

\section{RESULTS AND DISCUSSION}

The atomic coordinates and isotropic thermal parameters with their standard deviations are given

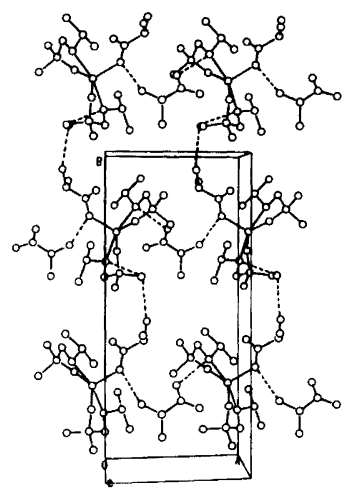

Table 1. Fractional atomic coordinates $\left(x 10^{4}\right)$ and isotropic thermal parameters for non-hydrogen atoms.

\begin{tabular}{lcccc}
\hline & $x$ & $y$ & \multicolumn{1}{l}{$z$} & $B_{\text {eq }}\left(\AA^{2}\right)$ \\
\hline Zn & $-902(1)$ & 2500 & $1248(1)$ & $3.78(3)$ \\
O1 & $1116(6)$ & $3029(3)$ & $1813(6)$ & $4.0(3)$ \\
O2 & $620(7)$ & $3877(4)$ & $-44(8)$ & $5.8(4)$ \\
O3 & $3103(8)$ & $4578(3)$ & $1135(9)$ & $7.8(4)$ \\
O4 & $6740(7)$ & $1926(4)$ & $5288(9)$ & $7.7(4)$ \\
O5 & $5162(6)$ & $2576(4)$ & $3509(7)$ & $5.9(3)$ \\
O6 & $2633(7)$ & $2027(4)$ & $4247(8)$ & $6.0(4)$ \\
O7 & $2684(12)$ & $6074(5)$ & $2255(10)$ & $10.6(6)$ \\
N1 & $-95(8)$ & $1525(4)$ & $180(9)$ & $4.6(4)$ \\
N2 & $-961(8)$ & $1832(4)$ & $3067(9)$ & $4.3(4)$ \\
N3 & $-2358(7)$ & $3338(3)$ & $2135(7)$ & $3.0(3)$ \\
N4 & $-2244(8)$ & $2861(4)$ & $-935(8)$ & $5.3(4)$ \\
C1 & $12(12)$ & $989(5)$ & $1443(13)$ & $6.1(6)$ \\
C2 & $-1134(14)$ & $1087(5)$ & $2491(14)$ & $6.2(6)$ \\
C3 & $-816(17)$ & $584(6)$ & $3924(19)$ & $10.0(9)$ \\
C4 & $-2769(16)$ & $993(6)$ & $1556(16)$ & $8.2(8)$ \\
C5 & $1302(11)$ & $1588(5)$ & $-521(12)$ & $5.3(5)$ \\
C6 & $1874(15)$ & $893(6)$ & $-1032(15)$ & $8.7(8)$ \\
C7 & $993(12)$ & $2090(7)$ & $-1879(12)$ & $6.4(6)$ \\
C8 & $-3111(11)$ & $3741(6)$ & $683(12)$ & $4.8(5)$ \\
C9 & $-3646(11)$ & $3264(7)$ & $-759(11)$ & $5.8(6)$ \\
C10 & $-4289(13)$ & $3713(9)$ & $-2229(14)$ & $9.8(9)$ \\
C11 & $-4869(11)$ & $2755(6)$ & $-519(11)$ & $6.9(7)$ \\
C12 & $-1604(9)$ & $3809(5)$ & $3446(11)$ & $3.5(4)$ \\
C13 & $-2783(12)$ & $4308(5)$ & $3973(11)$ & $5.7(6)$ \\
C14 & $-778(10)$ & $3386(5)$ & $4870(10)$ & $4.6(5)$ \\
C15 & $1392(10)$ & $3612(4)$ & $1157(11)$ & $4.0(4)$ \\
C16 & $2847(10)$ & $3987(5)$ & $2060(12)$ & $4.5(5)$ \\
C17 & $2741(12)$ & $4207(6)$ & $3730(13)$ & $6.2(6)$ \\
C18 & $5431(11)$ & $2120(5)$ & $4557(12)$ & $5.2(5)$ \\
C19 & $4046(11)$ & $1730(5)$ & $4989(12)$ & $5.3(5)$ \\
C20 & $4088(15)$ & $966(6)$ & $4505(21)$ & $10.3(9)$ \\
\hline & & & &
\end{tabular}

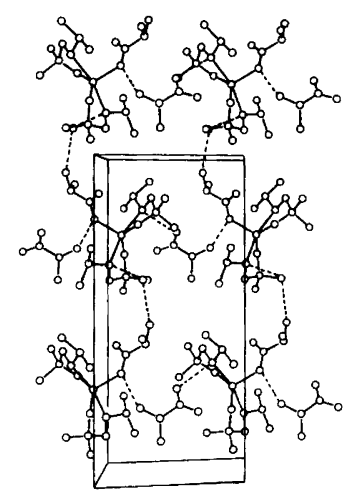

Fig. 1. Stereoscopic view along the $c$-axis of the packing. 


$$
\left[\mathrm{Zn}\left(\mathrm{C}_{7} \mathrm{H}_{18} \mathrm{~N}_{2}\right)_{2}\left(\mathrm{C}_{3} \mathrm{H}_{5} \mathrm{O}_{3}\right)\right]\left(\mathrm{C}_{3} \mathrm{H}_{5} \mathrm{O}_{3}\right) \cdot \mathrm{H}_{2} \mathrm{O}
$$

Table 2. Bond lengths $(\AA)$ and angles $\left({ }^{\circ}\right)$ with standard deviations in parentheses.

\begin{tabular}{|c|c|c|c|c|c|}
\hline $\begin{array}{l}\mathrm{Zn}-\mathrm{O} 1 \\
\mathrm{Zn}-\mathrm{N} 2 \\
\mathrm{Zn}-\mathrm{N} 4 \\
\mathrm{Zn}-\mathrm{N} 1 \\
\mathrm{Zn}-\mathrm{N} 3\end{array}$ & $\begin{array}{l}2.009(5) \\
2.004(8) \\
2.095(6) \\
2.234(8) \\
2.264(7)\end{array}$ & $\begin{array}{l}\mathrm{O} 1-\mathrm{Zn}-\mathrm{N} 2 \\
\mathrm{O} 1-\mathrm{Zn}-\mathrm{N} 4 \\
\mathrm{~N} 2-\mathrm{Zn}-\mathrm{N} 4 \\
\mathrm{~N} 1-\mathrm{Zn}-\mathrm{O} 1 \\
\mathrm{~N} 1-\mathrm{Zn}-\mathrm{N} 2\end{array}$ & $\begin{array}{r}107.1(2) \\
110.9(3) \\
141.9(3) \\
99.5(3) \\
81.8(3)\end{array}$ & $\begin{array}{l}\mathrm{N} 1-\mathrm{Zn}-\mathrm{N} 4 \\
\mathrm{~N} 1-\mathrm{Zn}-\mathrm{N} 3 \\
\mathrm{~N} 3-\mathrm{Zn}-\mathrm{O} 1 \\
\mathrm{~N} 3-\mathrm{Zn}-\mathrm{N} 2 \\
\mathrm{~N} 3-\mathrm{Zn}-\mathrm{N} 4\end{array}$ & $\begin{array}{r}94.4(3) \\
164.3(3) \\
96.2(3) \\
94.3(3) \\
79.2(3)\end{array}$ \\
\hline $\begin{array}{l}\mathrm{N} 1-\mathrm{C} 1 \\
\mathrm{C} 1-\mathrm{C} 2 \\
\mathrm{C} 2-\mathrm{N} 2 \\
\mathrm{C} 2-\mathrm{C} 3 \\
\mathrm{C} 2-\mathrm{C} 4 \\
\mathrm{~N} 1-\mathrm{C} 5 \\
\mathrm{C} 5-\mathrm{C} 6 \\
\mathrm{C} 5-\mathrm{C} 7\end{array}$ & $\begin{array}{l}1.466(13) \\
1.492(18) \\
1.487(12) \\
1.524(18) \\
1.504(17) \\
1.481(13) \\
1.504(17) \\
1.474(15)\end{array}$ & $\begin{array}{l}\mathrm{Zn}-\mathrm{N} 1-\mathrm{C} 1 \\
\mathrm{Zn}-\mathrm{N} 1-\mathrm{C} 5 \\
\mathrm{C} 1-\mathrm{N} 1-\mathrm{C} 5 \\
\mathrm{~N} 1-\mathrm{C} 1-\mathrm{C} 2 \\
\mathrm{C} 1-\mathrm{C} 2-\mathrm{N} 2 \\
\mathrm{C} 1-\mathrm{C} 2-\mathrm{C} 3 \\
\mathrm{C} 1-\mathrm{C} 2-\mathrm{C} 4\end{array}$ & $\begin{array}{l}104.4(6) \\
117.4(6) \\
114.8(7) \\
113.8(8) \\
106.3(9) \\
111.4(10) \\
111.4(10)\end{array}$ & $\begin{array}{l}\mathrm{N} 2-\mathrm{C} 2-\mathrm{C} 3 \\
\mathrm{~N} 2-\mathrm{C} 2-\mathrm{C} 4 \\
\mathrm{C} 3-\mathrm{C} 2-\mathrm{C} 4 \\
\mathrm{Zn}-\mathrm{N} 2-\mathrm{C} 2 \\
\mathrm{~N} 1-\mathrm{C} 5-\mathrm{C} 6 \\
\mathrm{~N} 1-\mathrm{C} 5-\mathrm{C} 7 \\
\mathrm{C} 6-\mathrm{C} 5-\mathrm{C} 7\end{array}$ & $\begin{array}{l}109.8(9) \\
107.9(9) \\
110.0(10) \\
111.0(6) \\
113.8(9) \\
109.5(8) \\
110.7(9)\end{array}$ \\
\hline $\begin{array}{l}\mathrm{N} 3-\mathrm{C} 8 \\
\mathrm{C} 8-\mathrm{C} 9 \\
\mathrm{C} 9-\mathrm{N} 4 \\
\mathrm{C} 9-\mathrm{C} 10 \\
\mathrm{C} 9-\mathrm{C} 11 \\
\mathrm{~N} 3-\mathrm{C} 12 \\
\mathrm{C} 12-\mathrm{C} 13 \\
\mathrm{C} 12-\mathrm{C} 14\end{array}$ & $\begin{array}{l}1.483(11) \\
1.514(14) \\
1.486(14) \\
1.518(16) \\
1.491(16) \\
1.471(10) \\
1.538(14) \\
1.504(12)\end{array}$ & $\begin{array}{l}\mathrm{Zn}-\mathrm{N} 3-\mathrm{C} 8 \\
\mathrm{Zn}-\mathrm{N} 3-\mathrm{C} 12 \\
\mathrm{C} 8-\mathrm{N} 3-\mathrm{C} 12 \\
\mathrm{~N} 3-\mathrm{C} 8-\mathrm{C} 9 \\
\mathrm{C} 8-\mathrm{C} 9-\mathrm{N} 4 \\
\mathrm{C} 8-\mathrm{C} 9-\mathrm{C} 10 \\
\mathrm{C} 8-\mathrm{C} 9-\mathrm{C} 11\end{array}$ & $\begin{array}{l}105.6(5) \\
118.5(5) \\
111.8(7) \\
112.2(8) \\
105.2(7) \\
109.5(11) \\
112.6(8)\end{array}$ & $\begin{array}{l}\text { N4-C9-C10 } \\
\text { N4-C9-C11 } \\
\text { C10-C9-C11 } \\
\text { Zn-N4-C9 } \\
\text { N3-C12-C13 } \\
\text { N3-C12-C14 } \\
\text { C13-C12-C14 }\end{array}$ & $\begin{array}{l}112.2(9) \\
108.9(10) \\
108.5(8) \\
113.9(5) \\
111.5(6) \\
110.8(7) \\
109.5(8)\end{array}$ \\
\hline $\begin{array}{l}\mathrm{C} 15-\mathrm{O} 1 \\
\mathrm{C} 15-\mathrm{O} 2 \\
\mathrm{C} 15-\mathrm{C} 16 \\
\mathrm{C} 16-\mathrm{O} 3 \\
\mathrm{C} 16-\mathrm{C} 17\end{array}$ & $\begin{array}{l}1.281(10) \\
1.210(10) \\
1.524(11) \\
1.410(12) \\
1.501(15)\end{array}$ & $\begin{array}{l}\mathrm{Zn}-\mathrm{O} 1-\mathrm{C} 15 \\
\mathrm{O} 1-\mathrm{C} 15-\mathrm{O} 2 \\
\mathrm{O} 1-\mathrm{C} 15-\mathrm{C} 16 \\
\mathrm{O} 2-\mathrm{C} 15-\mathrm{C} 16\end{array}$ & $\begin{array}{l}124.3(5) \\
126.7(8) \\
113.4(7) \\
119.9(8)\end{array}$ & $\begin{array}{l}\mathrm{C} 15-\mathrm{C} 16-\mathrm{O} 3 \\
\mathrm{C} 15-\mathrm{C} 16-\mathrm{C} 17 \\
\mathrm{C} 17-\mathrm{C} 16-\mathrm{O} 3\end{array}$ & $\begin{array}{l}107.6(7) \\
113.0(8) \\
110.9(8)\end{array}$ \\
\hline $\begin{array}{l}\mathrm{C} 18-\mathrm{O} 4 \\
\mathrm{C} 18-\mathrm{O} 5 \\
\mathrm{C} 18-\mathrm{C} 19 \\
\mathrm{C} 19-\mathrm{O} 6 \\
\mathrm{C} 19-\mathrm{C} 20\end{array}$ & $\begin{array}{l}1.246(11) \\
1.226(12) \\
1.535(14) \\
1.391(11) \\
1.504(16)\end{array}$ & $\begin{array}{l}\mathrm{O} 4-\mathrm{C} 18-\mathrm{O} 5 \\
\mathrm{O} 4-\mathrm{C} 18-\mathrm{C} 19 \\
\mathrm{O} 5-\mathrm{C} 18-\mathrm{C} 19\end{array}$ & $\begin{array}{l}125.9(9) \\
116.1(8) \\
118.0(8)\end{array}$ & $\begin{array}{l}\text { C18-C19-O6 } \\
\text { C18-C19-C20 } \\
\text { C20-C19-O6 }\end{array}$ & $\begin{array}{l}112.3(8) \\
109.2(9) \\
109.5(8)\end{array}$ \\
\hline
\end{tabular}

in Table 1. Lists of structure factors and anisotropic thermal parameters can be obtained from the authors. The bond lengths and angles are listed in Table 2.

The structure consists of bis $\left(N^{1}\right.$-isopropyl-2methyl-1,2-propanediamine)[(S)-lactato $]$ zinc(II) cations, $(S)$-lactate ions and water molecules held together by hydrogen bonds and electrostatic forces (Fig. 1). The complex cation with the atomic labelling is shown in Fig. 2.

The coordination geometry around the zinc(II) ion can be considered as distorted trigonal bipyramidal with two nitrogen atoms and a carboxyl oxygen atom in the equatorial sites and two nitrogen atoms bonded to the isopropyl groups in the axial positions. The zinc(II) atom deviates only $0.03(1)$ $\AA$ from the equatorial plane (N2-N4-O1) and the axial bonds $[2.234(8)$ and $2.264(7) \AA]$ are $0.14-$ $0.26 \AA$ longer than the equatorial ones $[2.004(8)-$ $2.095(6) \AA]$, as has been suggested for trigonalbipyramidal coordination. ${ }^{12}$ Both equatorial and axial bond angles show marked distortion towards a square-pyramidal geometry due to the out-of trigonal-plane chelation of the diamine ligands and nonbonding interactions. Similar geometry about the zinc(II) ion is found in $\mathrm{Zn}$ (acetylacetone) ${ }_{2} \mathrm{H}_{2} \mathrm{O}^{13}$ and in $\mathrm{Zn}$ (L-serinato $)_{2}{ }^{14}$ where acetylacetone and $\mathrm{L}$-serinate groups form six- and five-membered rings, respectively, with $\mathrm{Zn}$.

The two diamine rings in the complex cation assume an asymmetric gauche configuration. The asymmetry in the ring $\mathrm{Zn}-\mathrm{N} 1-\mathrm{C} 1-\mathrm{C} 2-\mathrm{N} 2$, where the carbon atoms $\mathrm{C} 1$ and $\mathrm{C} 2$ deviate 0.08 and $-0.57 \AA$ from the plane $\mathrm{N} 1-\mathrm{Zn}-\mathrm{N} 2$, is 


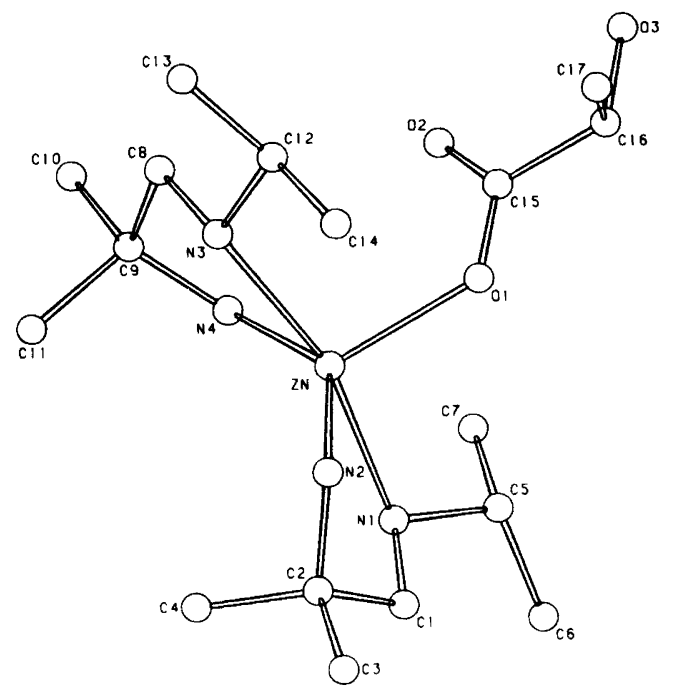

Fig. 2. View of the complex cation.

greater than in the ring $\mathrm{Zn}-\mathrm{N} 3-\mathrm{C} 8-\mathrm{C} 9-\mathrm{N} 4$, where $\mathrm{C} 8$ and $\mathrm{C} 9$ deviate 0.30 and $-0.40 \AA$ from the plane $\mathrm{N} 3-\mathrm{Zn}-\mathrm{N} 4$. It is not immediately obvious why the former ring is so buckled but it is likely that different hydrogen-bonding patterns involving the amine nitrogen atoms are responsible for the phenomenon. The two diamine chelate rings are in the same conformation $(\lambda)$ as in the corresponding copper(II) compound ${ }^{4}$ and in bis $\left(N^{1}\right.$ isopropyl-2-methyl-1,2-propanediamine)copper(II) succinate ${ }^{6}$ and fumarate, ${ }^{6}$ where trans chelation by diamine ligands slightly favours the $\lambda \hat{\lambda}$ or $\delta \delta$ arrangement. ${ }^{15}$ However in bis $\left(N^{1}\right.$-isopropyl-2methyl-1,2-propanediamine)copper(II) tartrate ${ }^{5}$ and malate $^{6}$ the $\delta \lambda$ configuration is found, owing to intramolecular interactions caused by the apical dicarboxylates.

Both the coordinated and uncoordinated carboxylate groups $(\mathrm{C}-\mathrm{COO})$ are planar within experimental error and the $\alpha$-hydroxyl oxygen atoms $\mathrm{O} 3$ and $\mathrm{O} 6$ deviate $0.15 \AA$ from the $\mathrm{C}-\mathrm{COO}$ planes. It should be noted that an intramolecular hydrogen bond between the $\alpha$-hydroxyl oxygen atom and a carboxyl oxygen atom is highly unfavourable although the $\mathrm{O} 2 \cdots \mathrm{O} 3$ and $\mathrm{O} 5 \cdots \mathrm{O} 6$ distances are $2.575(9)$ and $2.651(9) \AA$, respectively. ${ }^{16}$ The carboxyl $\mathrm{C}-\mathrm{O}$ bond lengths $[1.281(10)$ and $1.210(10) \AA]$ and $\mathrm{C}-\mathrm{C}-\mathrm{O}$ angles $[113.4(7)$ and $\left.119.9(8)^{\circ}\right]$ of the monodentate lactate group are significantly different and indicate double-bond character for the nonbonded carboxyl oxygen atom. This is consistent with the observation that in $\alpha$-hydroxy carboxylic acids and their salts the $\alpha$ hydroxyl group is almost coplanar with the $\mathrm{C}$ $\mathrm{COO}$ plane and in an eclipsed position relative to the double-bonded carboxyl oxygen atom. ${ }^{16}$ The carboxyl $\mathrm{C}-\mathrm{O}$ bond lengths of the ionic lactate group are equal within experimental error but the $\mathrm{C}-\mathrm{C}-\mathrm{O}$ angles still retain an inequivalency, the larger being towards the $\alpha$-hydroxyl group.

Complex cations and $(S)$-lactate ions appear to be connected by hydrogen bonds to chains parallel to the a axis (Fig. 1). The O1 $\cdots$ O6 distance of 2.913(8) $\AA$ and the $\mathrm{O} 5 \cdots \mathrm{N} 3(1+x, y, z)$ distance of 3.048(9) $\AA$ indicate weak hydrogen bonding between these atoms. In addition the $\mathrm{N} 2 \cdots \mathrm{O} 6$ distance of $3.139(9) \AA$ can be considered as indicating a very weak hydrogen bond. The $\mathrm{O} 4 \cdots \mathrm{N} 2(1+x, y, z)$ distance of 3.051(11) $\AA$ represents a purely electrostatic interaction rather than a hydrogen bond since this interaction is directed out of the plane of the carboxyl group and below the oxygen lone-pair lobe assuming $s p^{2}$ hybridization for carboxyl oxygen atoms). Water molecules join the chains together in the $b$ and $c$ directions. The $\mathrm{O} 3 \cdots \mathrm{O} 7$ distance of $3.030(12) \AA$ indicates a very weak and the $\mathrm{O} 7 \cdots \mathrm{N} 1$ $(-x, 1 / 2+y,-z)$ distance of $2.870(11) \AA$ a weak hydrogen bond between chains in the direction of the $b$ axis. The The O $7 \cdots \mathrm{O} 4(1-x, 1 / 2+y, 1-z)$ distance of 2.601(12) $\AA$ is the shortest hydrogen- 
bond distance in the structure and it joins layers represented in Fig. 1 together in the direction of the $c$ axis.

The packing of the complex cations, (S)-lactate ions and water molecules in the present structure is similar to that in the corresponding copper(II) compound. Neither compound has any unusual feature in the bond lengths abd angles of the diamine ligands or lactate groups. The main difference arises from the stereochemistry of the metal ions. In the copper(II) compound the geometry about the metal atom is a distorted square pyramid with the basal $\mathrm{Cu}-\mathrm{N}$ bond distances on average 0.10 $\AA$ shorter than the apical $\mathrm{Cu}-\mathrm{O}$ distance of $2.16 \AA$. Similar coordination geometry around zinc(II) is found in [5,10,15,20-tetrakis(4-pyridyl)porphinato $]$ (pyridine)zinc(II) ${ }^{17}$ and [5-\{2-\{[2-(3-pyridyl)ethyl]carbonylamino $\}$ phenyl $\}-10,15,20$-triphenylporphinato]zinc(II) ${ }^{18}$ where basal $\mathrm{Zn}-\mathrm{N}$ bond distances are also $0.10 \AA$ shorter than the apical $\mathrm{Zn}-\mathrm{N}$ bond distances of $2.15 \AA$. Gillespie ${ }^{12}$ has shown in terms of the theory of valency-shell electron-pair repulsion that trigonal-bipyramidal geometry is slightly preferred to square-pyramidal for transition elements with $d^{10}$ configuration. In the above two zinc(II) porphin complexes, however, polydentate ligands prevent the formation of a trigonal bipyramid. In the present zinc(II) compound the preferred trigonal-bipyramidal configuration is found, though markedly distorted.

\section{REFERENCES}

1. Näsänen, R., Tilus, P., Lindell, E. and Eskolin, E. Suom. Kemistil. B 45 (1972) 111.

2. Kansikas, J. and Hämäläinen, R. Finn. Chem. Lett. (1977) 118.

3. Kansikas, J. and Pajunen, A. Acta Crystallogr. B 36 (1980) 2423.

4. Ahlgrén, M. and Hämäläinen, R. Finn. Chem. Lett. (1975) 211.

5. Kansikas, J. and Hämäläinen, R. Finn. Chem. Lett. (1978) 54.

6. Kansikas, J. Private communication.

7. Ahlgrén, M. Ann. Acad. Sci. Fenn. Ser. A 2 No. 187 (1979) 23.

8. International Tables for $X$-Ray Crystallography, Kynoch Press, Birmingham 1974, Vol. 4, p. 149.

9. Cromer, D. T. and Mann, J. B. Acta Crystallogr. A 24 (1968) 321.

10. Stewart, R. F., Davidson, E. R. and Simpson, W. T. J. Chem. Phys. 42 (1975) 3175.
$\left[\mathrm{Zn}\left(\mathrm{C}_{7} \mathrm{H}_{18} \mathrm{~N}_{2}\right)_{2}\left(\mathrm{C}_{3} \mathrm{H}_{5} \mathrm{O}_{3}\right)\right]\left(\mathrm{C}_{3} \mathrm{H}_{5} \mathrm{O}_{3}\right) \cdot \mathrm{H}_{2} \mathrm{O}$

11. Stewart, J. M., Ed., The $X$-Ray System, Version of 1976, Technical Report TR-446, Computer Science Center, University of Maryland, College Park 1976.

12. Gillespie, R. J. J. Chem. Soc. (1963) 4679.

13. Lippert, E. L. and Truter, M. R. J. Chem. Soc. (1960) 4996.

14. Van Der Helm, D., Nicholas, A. F. and Fisher, C. G. Acta Crystallogr. B 26 (1970) 1172.

15. Corey, E. J. and Bailar, J. C. J. Am. Chem. Soc. 81 (1959) 2620.

16. Kanters, J. A., Kroon, J., Peerdeman, A. F. and Schoone, J. C. Tetrahedron 23 (1967) 4027.

17. Collins, D. M. and Hoard, J. L. J. Am. Chem. Soc. 92 (1970) 3761.

18. Bobrik, M. A. and Walker, F. A. Inorg. Chem. 19 (1980) 3383.

Received March 24, 1982. 